University for Business and Technology in Kosovo

UBT Knowledge Center

UBT International Conference

2015 UBT International Conference

Nov 7th, 9:00 AM - 5:00 PM

\title{
Creating Urban Sense of Community through Façades
}

\author{
Binak Beqaj \\ University for Business and Technology, bbeqaj@ubt-uni.net \\ Blerta Vula Rizvanolli \\ University for Business and Technology, blerta.vula@ubt-uni.net \\ Gent Hasimja \\ University for Business and Technology, gent.hasimja@ubt-uni.net
}

Follow this and additional works at: https://knowledgecenter.ubt-uni.net/conference

Part of the Architecture Commons

\section{Recommended Citation}

Beqaj, Binak; Rizvanolli, Blerta Vula; and Hasimja, Gent, "Creating Urban Sense of Community through Façades" (2015). UBT International Conference. 53.

https://knowledgecenter.ubt-uni.net/conference/2015/all-events/53

This Event is brought to you for free and open access by the Publication and Journals at UBT Knowledge Center. It has been accepted for inclusion in UBT International Conference by an authorized administrator of UBT Knowledge Center. For more information, please contact knowledge.center@ubt-uni.net. 


\title{
Creating Urban Sense of Community through Façades
}

\author{
Binak Beqaj ${ }^{1}$, Blerta Vula Rizvanolli², Gent Hasimja ${ }^{3}$ \\ 1,2,3 Department of Architecture, UBT - Higher Education Institution, Pristina, Kosovo \\ $\left\{\right.$ bbeqaj $^{1}$, blerta.vula ${ }^{2}$, gent.hasimja $\left.{ }^{3}\right\} @$ ubt-uni.net
}

\begin{abstract}
Urbanization is a continuous process, affected with different elements in different development periods.

Knowing that urbanization is a multi-sectorial process oriented to different activities with the aim of harmonizing urban -architectural landscape with natural landscape to achieve as much as possible urban sense of community living there (in behavior or sociological aspect).

Considering that role of different buildings all over urban area not only through their interior view functions-destinations but also through their exterior view architectural form-façades is unsubstituted; this research is trying to give answer on question:

At what level façades can create urban sense of community living in urban area?

Searching for answer, was developed a research method "consumer preference for product" (called "Utility method"), where through survey are shown their preferences on observation on their actual made choices, this through:
\end{abstract}

- Visual representation (materialization)

- Visual context (integration)

- Visual integration(form-complexity, harmony)

- Visual socialization (behavior reflection on behavior)

- Visual aesthetics (color, rhythm )

Keywords: urbanization, community, sense, process, façades, visual, landscape.

\section{Introduction}

Population expansion, rapid urbanization, intensive construction, the quality of construction in urban areas, namely the confused structure of the buildings facades which shape the urban landscape, may impact the de-harmonization of urban life, increase inconsistencies and stress and behaviour in citizens when dealing with urban life, therefore directly affecting the shaping of urban sense of community.

Besides intensive construction, transformation of building facades also accured and along with this shaping of the urban community feeling related to: 


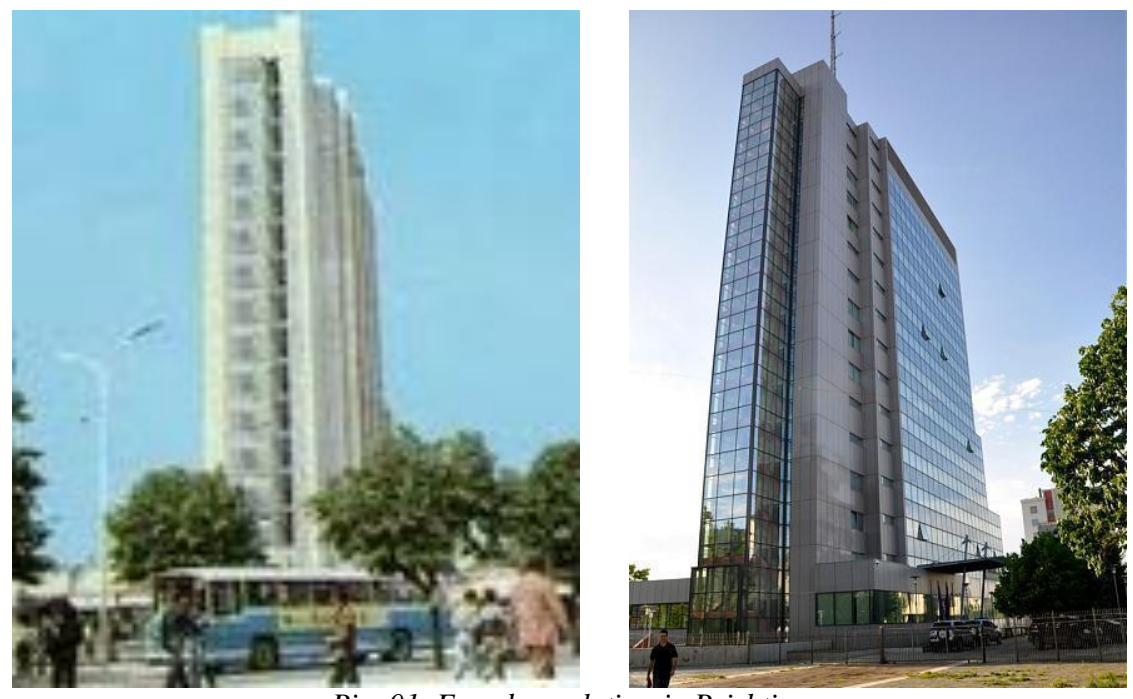

Pic. 01. Façade evolution in Prishtina

- Energy efficiency and micro-climatic influence in the area

- Openings and communication

- Urban-architectural effects

- Perception and identity

- The level of viability and accessibility in public spaces

This fact shows that the facades connect the interior space with exterior and as well associate both these spaces with people (community) through perception and appearance. Thus, architectural facades are justified as the most compelling visual aspect in shaping the character of the city and also a very compelling aspect on the contribution towards the development of urban spaces sense.

\section{De veloping trends}

It is known that rapid urbanization is accompanied by massive constructions in urban areas, related to the feelings and behaviour of citizens is significantly related to the answer on the question:

$>$ At what level façades can create urban sense of community living in urban area?

So far the practice to improve the facades is mainly concentrated in terms of revitalizing the commercial corridors and in most cases there is lack of chronologically information on their development, repair and maintenance. Therefore the question is what made them "successful" and by which parameters we can determine and classify success? In order to answer the above question a research method called "customer preferences for the product" was applied by modify ing it to "citizen preferences for facades" also known as "Utility Method". By using questionnaires and case studies this method shows citizens preferences on actual urban solutions and also their future preferences on the facades on the urban area the citizens live in. In addition the following indicators are used as valuators of citizen preferences:

Visual presentation (materialization)

- Visual perception (perception and integration)

- Visual integration (shape, complexity, harmony)

- Visual socialization (showing reflection on behaviour)

- Visual aesthetics (colours, rhythm) 
Both case studies performed in Prishtina and Tirana, confirmed that facade improvement in urban areas can be considered as an indicator of success in changing the overall urban landscape and by doing so it also influences in community behaviour in terms of how they see them, how they use them or re-use the facades in the context of socio-economic dynamics of the development of the area.

Quality of the urban landscape is a result of direct impact of facade aesthetics and also has direct impact on how citizens feel in that environment, thus both building facades and citizen behaviour are closely related to each other within the framework of the whole urban environment.

The character and function of buildings changes together with time and also with changes in terms of increasing or decreasing the resident urban area, therefore with the evolution of the buildings functions the structure of the facades on these buildings changes together with the urban community behaviour. This study intends to analyze and present the dy namic development of facades presented in different ways; built within the framework of modern architectural forms and materializations, altered as a result of economic development trends, or restored as a result of protection of cultural and architectural heritage; in all cases indicating interconnection between nature, culture, economic and social aspects and urban space with community feelings and behaviour. Besides the architectural effects in buildings, facades, also have psy chological effects on citizens with regard to their behaviour in space, both these together affect the overall urban environment, as the shapes, textures, materials, colours, lighting not only create a nice urban landscape but also affect the accessibility of spaces (especially public ones) in accordance with the dy namics of needs and aspirations of the citizens. One of the best examples which are presented in Pic.02 shows the revitalization of the façade of a cultural heritage building. The reconstructed façade, reshape the entire environment around the building and re-designate the usage of the public space, a space which can be used for resting, mediation, meetings, readings, etc. Another modern building with a special interactive façade is shown in Pic.02. This building would not have the same impact on pedestrians without audio-visual equipment which presents advertisements and other important information which has a big impact in the people in the surrounding area.
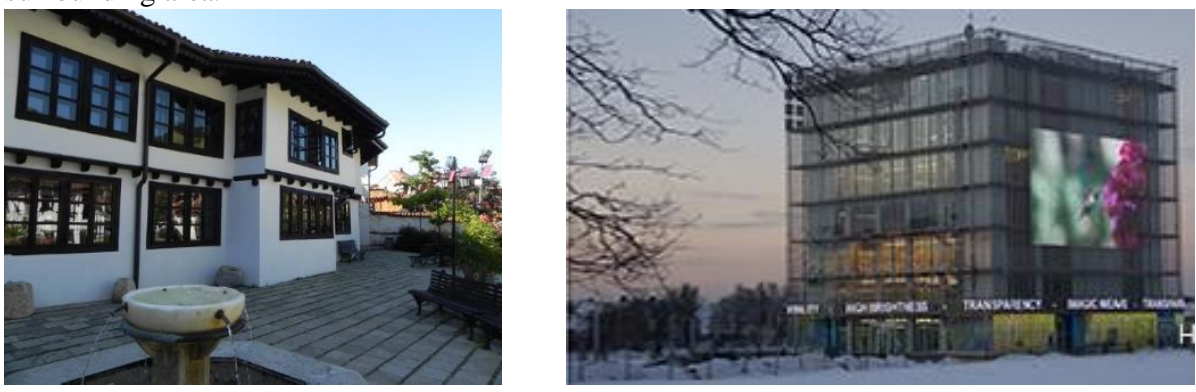

Pic. 02. Cultural Heritage Building façade and Modern interactive Building facade

\section{Study Case}

As we mentioned above building's architecture, urban landscape and public spaces, determine the way of thinking and people's behaviour in urban space in that regard.

Development trends of facade improvement, until recently have been seen as a way to revitalize the commercial corridors so called "shopping streets", often ignoring chronological information for the space development and more sustainable development. The research work regarding the impact of facades in urban / architectural space, should be related to the context the facades offer within the space that can be analyzed as part of a comprehensive system primarily related to corporate identity based on Visual presentation (materialization), Visual perception (perception and integration), Visual integration (shape, complexity, harmony), Visual socialization (showing reflection on behaviour) and Visual aesthetics (colours, rhythm).

Impressive impact of architectural facades in urban space and humans is also studied by Le Corbusier, with a focus on the degree and the extent of urban activities.

A survey was undertaken with the aim of identifying some key parameters to regulate the architecture of the cities in urban context. Structure of respondents was mixed so we could achieve more 
comprehensive results. Around 120 persons have replied the questionnaires out of which 5\% Politicians, 2\% Psychologist, 33\%Planers, 40\% Local citizens and 20\% Transiting citizens.

\section{DO WE HAVE \\ SYMBOLIC FACADES

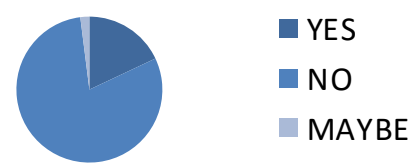

With the first question we aim to understand if Prishtina has sy mbolic facades which identify a certain neighbourhood and which set the direction for citizen's orientation in the city. Almost $80 \%$ of the answers were No, with only few answers related to administrative buildings in the city centre.

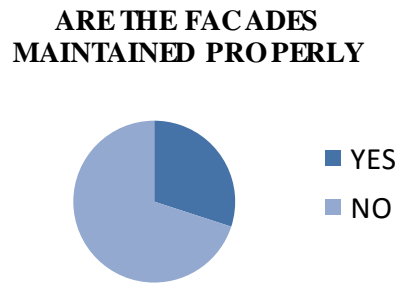

In the question are the facades maintained properly in the public and private buildings in Prishtina, the majority of the respondent's answers were yes, but only in the public owned buildings, while as long as the ownership of common areas of private buildings is not legally solved, it is difficult to have properly maintained facades.

\section{FACADES REFLEC TIO N IN URBAN ENVIRO NMENT}
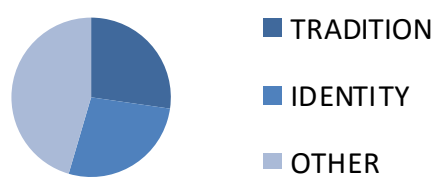

While in the question related the reflection and identity of the facades in Prishtina, most of the respondents said that they show tradition especially the buildings in the city centre and identity reflection the buildings destination.

Moreover additional question fulfilling the overview of the building's façades impact has been done:

- How much does the regulation of facades and urban landscape influence the city identity feeling?

- How much does the regulation of facades and urban landscape impact the urban sense of the citizens?

- How much does the regulation of facades and urban landscape impact the citizens in regard to safety feeling?

- How much does the regulation of facades and urban landscape impact the city organization and orientation?

- How much does the regulation of facades and urban landscape impact on the social and sociological aspect of the residents?

- How much does the regulation of facades and urban landscape impact the increase economic value of the building and urban space? 
The result of the survey with citizens regarding architectural facades as part of urban space

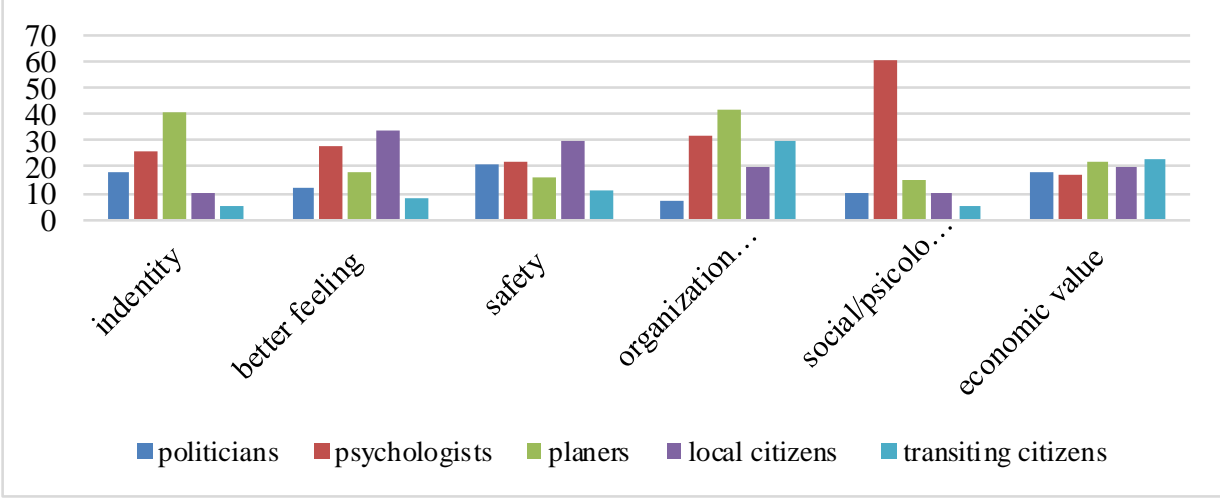

The planers supports the theory that the facades shall represents country's identity while citizens and psychologist say that well designed building's facades would impact a better feeling and have a big social influence on the people living in Prishtina. A better feeling reflects safety meanwhile according to planers good facades would help people orientation within the city.

Facades are the face of the building, the first thing that residents see and perceive, so the quality and design of the facades have a high impact in the total economic value of the building. This was the question were most of the respondents agreed unanimously.

A comparison between Tirana and Prishtina was undertaken to see if the results achieved in Tirana by façade colouring could be replied in Prishtina with the same impact. Color is perhaps the most easily seen and recognized physical aspect in our surroundings. Color is essential to the way humans experience the world - phy sically, emotionally and psychologically.

Colors communicate symbolic messages, contribute to order and differentiation, and indicate special functions. Most importantly, color crucially influences "the statement, effect, and acceptance of objects and space"

Tirana is a dynamic city of noise and contrasts, where the modern lifestyle meets old traditions. In 2000, the may or of Tirana, Edi Rama was facing a post communist city with illegal buildings, high crime levels, no public spaces and a gray colour which owed the city: gray in buildings, gray in roads and therefore gray in people's life

The decision to paint a whole city in bright colour was one of the biggest risks that a may or could take, but as a painter, the Tirana mayor was conscious about colour effects on people and their psychology. Big noise raised up: "What is this? What is happening? What are colors doing to us?"A decline in crime throughout the city, and an increase in taxpaying after this painting the exteriors and facades.
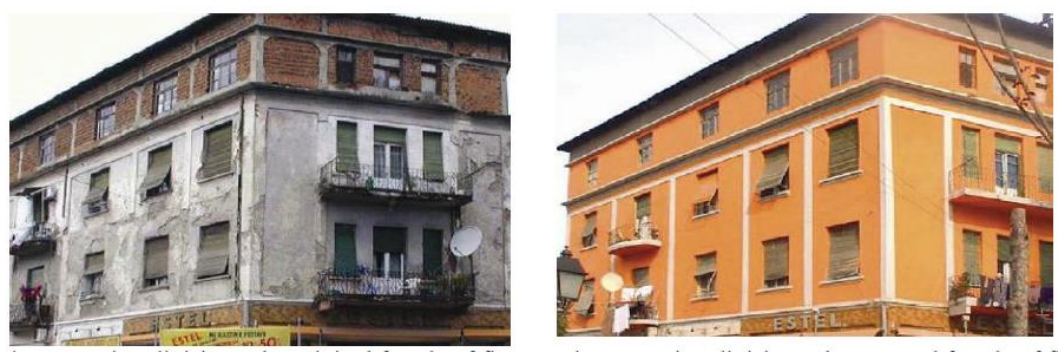

Pic. 03. First building in bright colour in Tirana

The same case was used to simulate the regulation of the facades in Dardania neighbourhood where we can see the impact of colour, shape and rhy thm to the regulation of the view and perception. 

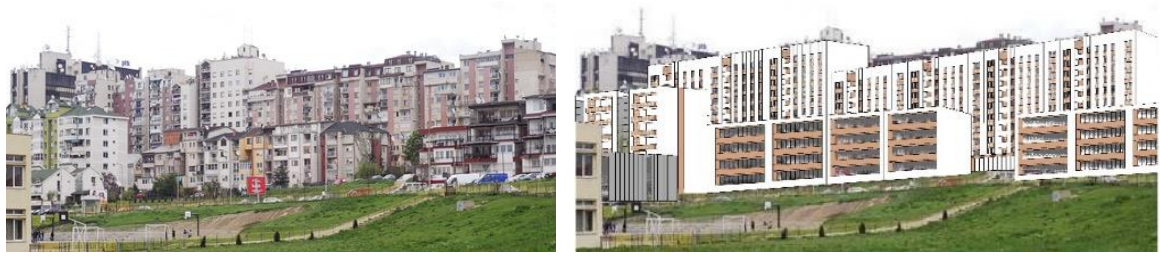

Pic. 04. Simulation of façade colours change in Dardania - Prishtina

\section{Conclusions}

Finally based on the research findings it results that facades as elements of urban landscape / architecture are of special importance for urban landscape as a whole and people to whom these spaces belong and are used by. These influences are mostly reflected in:

- Architectonic perspective through urban landscape configuration

- Psychological effects through feelings, experiences or behaviours

- Visualisation in regard to interior/exterior, communication and correlation in this regard.

- Continuity of development through continuous improvement by providing the harmony of the existing facades with new ones

From what said above, the impact of architectural facades in developed areas is huge, primarily because of the influence in the character of the city, giving the sense of urban space more than any other element and this for the fact that and aesthetic quality of urban space, considered as key impact elements in relation to how people feel, act and correlate to urban surroundings. "Unfortunately, when we choose how to live or move, most of us are as free as our thoughts are. Our options are limited and they are defined by, planners, engineers, politicians, architects, economists; to which inculcate their individual values in the urban landscape" (Ch. Montgomery "Happy City").Finally, the reconstruction of facades and along with this the regeneration of urban space, encourage people to a better life with less environmental degradation and social awareness. Therefore facades are considered more than decoration, more than wrapping the building; they may as well be considered as the face of the city.

\section{References}

1. Charles Montgomery, "Transforming our lives through urban design”, (2013)

2. Setha M. Low, Neil Smith, "The politics of public space", (2006)

3. Peter John, “Analyzing public policy”, (2013)

4. Binak Beqaj, "Zhvillimi urban, planifikimi dhe dizajni”, (2015)

5. Jan Gehl, "Life between buildings using public space", (2011)

6. Jan Gehl, "Cities for people", (2010)

7. Ministry for the Environment, Wellington, "The Value of Urban Design. The Economic, Environmental and Social Benefits of Urban Design". (2005)

8. Baltic University Urban Forum, "Built Environment and Revitalization", (2006)

9. John Chang, "The problematization of urban spravl in the United States", (2006)

10. EU Commission, "Making our Cities Attractive and Sustainable", (2010)

11. World Bank, "Measuring Growth and Change in Metropolitan Form", (2012)

12. World Bank, "Vleresimi i sektorit urban ne Shqiperi”, (2007)

13. Aguinar and Pernao. 2010. Colour and participative processes in urban requalification, Social housing in Portugal. First International Conference 2010, Portugal

14. Boeri, C. 2010. A perceptual approach to the urban colour reading, Colour and Light in Architecture, Universita luav di Venezia, Venice

15. Erida Abazi, Sokol Dervishi, "Colour and Participative Process in Urban Requalification of Tirana", (2014)

16. Amir Hossein Askari, Kamariah Binti Dola, "Influence of Building Façade Visual Elements on Its Historical Image", (2009)

17. Erica Janine Maust, "Placing Color: Architectural Color \& Façade Improvement Programs in Commercial Corridor", (2013) 